J. Product. \& Dev., 25(1): 25- 37 (2020)

\title{
EXTENDED SHELF LIFE OF TALLAGA CHEESE BY NATURAL PRESERVATIVES
}

\author{
A. E. Saleh; Abd El-Malek, A. F., and Moussa, M. A.M., \\ Dairy Res. Dept., Animal Pro. Res. Institute, Agric. Res. Center, Ministry \\ of Agric, Egypt.Email: Abed.saleh@yahoo.com
}

\section{ABSTRACT}

Tallaga cheese was made from pasteurized buffalo's milk, divided into four equal parts in addition to the control. Three types of essential oils; garlic, ginger and clove were added (0.5\%) and 5\% propolis extract. Tallaga cheese was analyzed for chemical, sensory and microbiological characteristics at fresh, 15, 30 and 45 days of storage, refrigerated at $\left(5 \pm l^{\circ} \mathrm{C}\right)$. Gross composition of the resultant cheese samples was within the composition of cold storage Egyptian Tallaga cheese.

The moisture and $\mathrm{pH}$ values of cheese samples control and all treatments decreased as the storage period progressed. Tallaga cheese treatment's and control samples increased in fat, total nitrogen (TN), SN, TVFA, ash during progressing period of storage. Tritatable acidity was detected during the storage period. The total bacterial count $\left(\times 10^{6}\right.$ cfu/g) in control was (42), $T_{1}$ (33), $T_{2}$ (32), $T_{3}$ (33) and $T_{4}$ (31) when fresh, and decreased gradually during storage. The results show that no yeasts and molds were detected in fresh samples. However, the counts started to be detected and counted after 30 days in all treatments including control. Coliform content was also not detected in fresh cheese in control and all treatments, but at the end of the storage period the cornet were lower in all treatments measured $T_{1}(N D), T_{2}(0.07$ $\left.x 10^{2}\right) T_{3}(N D)$ and $T_{4}\left(0.09 \times 10^{2}\right)$ compared to control $\left(0.4 \times 10^{2}\right)$.

Sensory evaluation of Tallaga cheese manufactured by adding $0.5 \%$ essential oil and 5\% propolis extract (T4, T2, T1 and T3) gained higher score for appearance, body and texture and flavor than control at the end of the storage period.

Conclusively, results of this study showed that can produce high quality Tallaga cheese and accept the use of some essential oils can be recommended. The finished product showed improved body texture, better cheese flavor. Moreover, prolong the life of the cheese. Much research is needed to continue applying these essential oils in compounds with others and with each other atural preservatives, and 
also investigate the effect of these oils on the spoilage in other types of dairy foods

Key words: Extended Shelf Life, Tallaga Cheese, Natural Preservatives

\section{INTRODUCTION}

Cheese is an integral part of the diet consumed by Egyptians. The most popular type of fresh soft cheese produced in Egypt was mentioned by (Abd El-Salam and Benkerroum, 2007). Several varieties of soft cheese are produced in Egypt. One of these varieties is the cold stored soft cheese (Tallaga). Tallaga cheese has a spreadable mellow soft body with a pleasant creamy taste (Houfi et al., 1979). Tallaga cheese is Egyptian unripened soft cheese, usually made from heated milk with adding low concentration of salt and stored in the refrigerator until consumption within two weeks (Mehanna and Rashed, 1990). Egyptian consumers demand for Tallaga cheese increases mainly because it's low salt content and mild taste. Tallaga cheese is made from skimmed cow or buffalo milk, or their mixtures cut into suitable pieces to be directly consumed as fresh cheese. One of the recent trends in cheese manufacture is the production of cheese with natural flavor and high nutritional value and good microbiological quality to the consumer in a short time. (Hosny et al., 2011). The shelf-life of refrigerated non-sterile dairy products, including cheese is generally limited 1-3 weeks (Salvador and Fiszman, 2004) depending upon the quality of the raw materials, processing conditions, and post processing conditions, and post processing handing.

Spices and herbs have played an important role in human life prehistoric times. They have been used not only for flavouring food but also for their anti- oxidative, preservative and medicinal properties (Ismael et al., 2006). Food scientists found that spices, their essential oils and their extracts are superior substances, which can be used as substitutes for the artificial hazardous preservatives (Bullerman et al., 1977). Some studies have reported the effect of some herbs and spices such as clove, ginger, garlic, cloves, marjoram, mustard all spices, black cumin, cumin and organa on preventing the growth and toxin production of Aspergillus, Alternaria and Penicillium (Hassan and El-Deeb, 1988). Herbs and spices are used daily mainly in food for their aroma and flavours. The flavour ingredient aldehydes, alcohols, terpenes, phenol, organic acid and estar, have not yet been fully identified (Abou Dawood, 1996). In addition to giving the flavour, spices serve to prolong the shelf- life of foods due to their bacteriostatic or bacterio-cidal activity, and some prevent rancidity by their antioxidant activity according to 
(Shelef et al., 1980). A lot of the essential oils of herbs and spices are active against various food- borne bacteria and molds according to (Aureli et al., 1992) and in some instances potent anti-carcinogenic agents (Bowles and Juneja, 1998), and/ or reduce processing requirements for their elimination in foods. The inhibitory effect of essential oils is due to the presence of aromatic nuclei containing a functional polar group (Saleh, 2018).

Today, herbs and spices are widely used in many foods for their distinctive aroma and flavours. Some spices increase the shelf life of food because of their antibacterial and bactericidal activity in addition to flavoring food (Shelef et al., 1980). Many spices and essential oils have a different activity for many bacteria transmitted by food contamination (antimicrobial activity) (Aureli et al., 1992); (Tassou et al., 1995) and (Gould, 1996). Several investigators used natural flavouring additives in some dairy products as flavours, preservates and antibacterial materials. (Abou Dawood, 1996), (AbdAlla et al., 2000), (El-Nemer et al., 2003) and (Hussein, 2004).

Garlic and ginger have been widely known to improve lipid metabolism, promoting the circulation of blood, preventing cardiovascular diseases and immunopotentiation with anticancer activity (Lawson, 1993). Ginger is considered the greatest natural preservative and bactericide. Indian studies showed that ginger extract inhibits the fungi which excreted aflatoxin (Sonia, 2011).

Propolis is a natural resinous bee product collected by honeybee workers, has gained popularity as an alternative medicine or food for health amelioration and disease prevention in various parts of the world, including the European Union, the United States of America and Japan. Propolis has antibacterial, antifungal and antiviral activities (Dabiza, 2006). Good hygiene and safe storage conditions play an important role in safety and quality food this led to the Consumers want the food with a few of artificial additives and chemical preservatives. Scientists make a lot of efforts to know the compounds to be used as safe alternatives to reduce chemicals.

So, the thrust of this study was to evaluate the potential of propolis extract, clove, ginger and garlic oils as preservatives and its efficacy on the storage quality of Tallaga cheese.

\section{MATERIALS AND METHODS}

\section{Materials}

Fresh buffalo's milk used in the present study was collected from the herds of Mehalet Moussa Experimental Station of experimental, animal production Research institute, Agricultural Research center, ministry of 
Agriculture. Salt "Iodized salt", produced by EL-Nasr Saline's, Calcium chloride (pure) was obtained from El-Nasr Pharmaceuticals Company in Alexandria. Microbial rennet powder was purchase from Semiramis International Trading, Cairo, Egypt.

\section{Essential oils:}

Clove, ginger and garlic essential oils were from the local market (Kafr El Sheikh, Egypt) and stored at $5 \pm 1^{\circ} \mathrm{C}$.

\section{Collection and Preparation of propolis:}

Propolis was collected from hybrid honey bee colonies at Kafr ElSheikh Governate. Soaked in distilled water at the ratio of 1:10 for 7 days with periodical shaking, and the filtered through Zeiss filter to obtain $10 \%$ sterilized extract.

\section{Experimental procedures:}

Fresh buffalo's milk was standardized to $6 \%$ fat, and then was heated at $72{ }^{0} \mathrm{C} / 15$ seconds, and cooled to $40{ }^{0} \mathrm{C}$, sodium chloride and calcium chloride were added at the range of $4 \%$ and $0.02 \%(\mathrm{w} / \mathrm{w})$ respectively. The milk was divided to five equal portions $20 \mathrm{~kg}$ each. The first portion was kept as control without additives as essential oils clove, ginger and garlic were added separately at the ratio of $0.5 \%$ to three portions of milk, while $10 \%$ propolis extract was added at the ratio of 5\% to the fifth milk portion. Tallaga cheese was made by the traditional method for making Domiati cheese (Fahmi and Shara, 1950). Microbial rennet powder was (5gm/100kg milk) was added to the prepared treatments then incubated at $40{ }^{0} \mathrm{C}$ untill full coagulation, scooped into cheese forms lived with cheese cloth and left to drain whey. The obtained fresh cheese was cut into pieces and stored in salted whey from the same berth at $5 \pm 1^{\mathrm{O}} \mathrm{C}$ and tested when fresh and after 15, 30 and 45 days of cold storage.

\section{Compositional analysis:}

Samples of cheese were analyzed when fresh then after 15, 30 and 45 days of storage period. Sample was thoroughly mixed in a ceramic jar and used for $\mathrm{pH}$ mean resents using $\mathrm{pH}$ meter (model SA 720). Tirtatable acidity, moisture, fat, ash, total solids, total nitrogen and soluble nitrogen were determined according to the method described by (AOAC, 2012). Direct distillation method is used to estimate total volatile fatty acids (TVFA) according to (Koiskowski, 1978), results were showed that as $\mathrm{ml}$ $0.1 \mathrm{~N} \mathrm{NaoH} / 100 \mathrm{gm}$. cheese. 
Microbiological analysis of produced cheese:

All samples were examined for total bacterial count (TBC), coliform and mould \& yeasts according to American public health association (APHA, 2003). All microbiological and chemical analysis was carried out in duplicate and the results as a mean for the three different samples.

\section{Sensory analysis:}

Organoleptic properties of cheese samples estimated according to (Pappas et al., 1996) at fresh, 15, 30 and 45 days of cold storage period $\left(5^{0} \mathrm{C} \pm 1\right)$. Ten panelists from the staff of Dairy department assessed the cheese, the maximum score points 40 for body and texture , 50 points for flavor and 10 points for appearance.

Statistical analysis:

SAS, (2004) computer program, GLM analysis of variance (ANOVA) was used for data analysis. The differences between means were detected by (Duncan`s Multiple Range test, 1955).

\section{RESULTS AND DISCUSSION}

\section{Chemical composition of cheese:}

As shown in Table (1), Tallaga cheese made with the different essential oils showed significant $(\mathrm{P}<0.05)$ higher moisture contents compared to control. The moisture contents all cheese treatments decreased significantly $(\mathrm{P}<0.05)$ as storage period progressed. The results are identical with (El-Kholy, 2005) and (Al- Jasser and Al-Dogan, 2009).

However, no marked differences were found in the fat content of cheese slightly low fat content in control and containing propolis extract. 
Table (1): Chemical composition of Tallaga cheeses treatments during storage period at $5^{\circ} \mathrm{c} \pm 1$.

\begin{tabular}{|c|c|c|c|c|c|c|}
\hline \multirow[t]{2}{*}{ Properties } & \multirow{2}{*}{$\begin{array}{c}\text { SP } \\
\text { (days) }\end{array}$} & \multicolumn{5}{|c|}{ Treatment groups* } \\
\hline & & Control & $T_{1}$ & $\mathbf{T}_{2}$ & $\mathbf{T}_{3}$ & $\mathbf{T}_{4}$ \\
\hline \multirow{4}{*}{$\begin{array}{l}\text { Moisture } \\
\text { (\%) }\end{array}$} & 0 & $58.40 \pm 0.01^{\mathrm{a}}$ & $58.60 \pm 0.01^{b}$ & $58.80 \pm 0.02^{\mathrm{d}}$ & $58.70 \pm 0.02^{\mathrm{c}}$ & $58.70 \pm 0.01^{\mathrm{c}}$ \\
\hline & 15 & $58.30 \pm 0.02^{\mathrm{a}}$ & $58.30 \pm 0.03^{\mathrm{a}}$ & $58.30 \pm 0.01^{\mathrm{a}}$ & $58.35 \pm 0.02^{b}$ & $58.30 \pm 0.03^{\mathrm{a}}$ \\
\hline & 30 & $57.20 \pm 0.02^{\mathrm{a}}$ & $57.40 \pm 0.02^{\mathrm{c}}$ & $57.50 \pm 0.01^{\mathrm{d}}$ & $57.35 \pm 0.03^{b}$ & $57.40 \pm 0.02^{\mathrm{c}}$ \\
\hline & 45 & $56.10 \pm 0.03^{\mathrm{a}}$ & $56.20 \pm 0.01^{\mathrm{c}}$ & $56.40 \pm 0.02^{\mathrm{d}}$ & $56.20 \pm 0.01^{\mathrm{c}}$ & $56.15 \pm 0.03^{\mathrm{b}}$ \\
\hline \multirow{4}{*}{$\begin{array}{l}\text { Fat } \\
(\%)\end{array}$} & 0 & $17.10 \pm 0.03^{\mathrm{a}}$ & $17.30 \pm 0.03^{\mathrm{c}}$ & $17.35 \pm 0.03^{\mathrm{d}}$ & $17.30 \pm 0.02^{\mathrm{c}}$ & $17.20 \pm 0.02^{\mathrm{b}}$ \\
\hline & 15 & $18.10 \pm 0.06^{\mathrm{a}}$ & $18.30 \pm 0.05^{\mathrm{c}}$ & $18.35 \pm 0.04^{\mathrm{d}}$ & $18.30 \pm 0.06^{\mathrm{c}}$ & $18.20 \pm 0.02^{b}$ \\
\hline & 30 & $19.00 \pm 0.04^{\mathrm{a}}$ & $19.40 \pm 0.06^{\mathrm{c}}$ & $19.40 \pm 0.02^{\mathrm{c}}$ & $19.40 \pm 0.03^{\mathrm{c}}$ & $19.20 \pm 0.06^{b}$ \\
\hline & 45 & $19.40 \pm 0.02^{\mathrm{a}}$ & $19.50 \pm 0.04^{b}$ & $19.50 \pm 0.06^{b}$ & $19.50 \pm 0.02^{b}$ & $19.40 \pm 0.01^{\mathrm{a}}$ \\
\hline \multirow{4}{*}{$\begin{array}{l}\text { Tirtatable } \\
\text { acidity } \\
(\%)\end{array}$} & 0 & $0.26 \pm 0.02^{\mathrm{a}}$ & $0.27 \pm 0.01^{b}$ & $0.27 \pm 0.02^{\mathrm{b}}$ & $0.27 \pm 0.01^{\mathrm{b}}$ & $0.30 \pm 0.01^{\mathrm{c}}$ \\
\hline & 15 & $0.30 \pm 0.01^{\mathrm{a}}$ & $0.32 \pm 0.02^{b}$ & $0.32 \pm 0.03^{b}$ & $0.33 \pm 0.02^{\mathrm{c}}$ & $0.34 \pm 0.03^{\mathrm{d}}$ \\
\hline & 30 & $0.36 \pm 0.03^{\mathrm{a}}$ & $0.45 \pm 0.03^{b}$ & $0.45 \pm 0.01^{b}$ & $0.45 \pm 0.03^{b}$ & $0.49 \pm 0.02^{\mathrm{d}}$ \\
\hline & 45 & $0.45 \pm 0.02^{\mathrm{a}}$ & $0.52 \pm 0.01^{\mathrm{c}}$ & $0.52 \pm 0.02^{c}$ & $0.51 \pm 0.01^{b}$ & $0.62 \pm 0.01^{\mathrm{d}}$ \\
\hline \multirow{4}{*}{$\begin{array}{l}\text { pH } \\
\text { values }\end{array}$} & 0 & $6.55 \pm 0.04^{\mathrm{d}}$ & $6.54 \pm 0.06^{\mathrm{c}}$ & $6.53 \pm 0.02^{b}$ & $6.54 \pm 0.04^{c}$ & $6.49 \pm 0.06^{\mathrm{a}}$ \\
\hline & 15 & $6.35 \pm 0.03^{b}$ & $6.46 \pm 0.04^{c}$ & $6.35 \pm 0.04^{b}$ & $6.40 \pm 0.02^{b}$ & $6.15 \pm 0.03^{\mathrm{a}}$ \\
\hline & 30 & $5.98 \pm 0.06^{b}$ & $6.00 \pm 0.08^{\mathrm{c}}$ & $6.01 \pm 0.04^{\mathrm{d}}$ & $6.00 \pm 0.08^{c}$ & $5.96 \pm 0.06^{\mathrm{a}}$ \\
\hline & 45 & $5.90 \pm 0.04^{\mathrm{d}}$ & $5.86 \pm 0.06^{\mathrm{c}}$ & $5.86 \pm 0.08^{c}$ & $5.85 \pm 0.04^{b}$ & $5.84 \pm 0.08^{\mathrm{a}}$ \\
\hline \multirow{4}{*}{$\begin{array}{l}\text { Total } \\
\text { nitrogen } \\
\text { TN } \\
(\%)\end{array}$} & 0 & $2.57 \pm 0.01^{\mathrm{a}}$ & $2.60 \pm 0.02^{b}$ & $2.63 \pm 0.01^{\mathrm{c}}$ & $2.60 \pm 0.01^{b}$ & $2.60 \pm 0.02^{b}$ \\
\hline & 15 & $2.50 \pm 0.04^{\mathrm{a}}$ & $2.52 \pm 0.03^{\mathrm{b}}$ & $2.52 \pm 0.04^{b}$ & $2.54 \pm 0.02^{\mathrm{c}}$ & $2.50 \pm 0.04^{\mathrm{a}}$ \\
\hline & 30 & $2.44 \pm 0.02^{b}$ & $2.46 \pm 0.04^{\mathrm{c}}$ & $2.42 \pm 0.02^{\mathrm{a}}$ & $2.44 \pm 0.04^{b}$ & $2.42 \pm 0.02^{\mathrm{a}}$ \\
\hline & 45 & $2.40 \pm 0.01^{b}$ & $2.38 \pm 0.01^{\mathrm{a}}$ & $2.38 \pm 0.01^{\mathrm{a}}$ & $2.40 \pm 0.01^{\mathrm{a}}$ & $2.38 \pm 0.01^{b}$ \\
\hline \multirow{4}{*}{$\begin{array}{l}\text { Soluble } \\
\text { nitrogen } \\
\text { SN }(\%)\end{array}$} & 0 & $0.28 \pm 0.01^{\mathrm{a}}$ & $0.35 \pm 0.02^{\mathrm{c}}$ & $0.35 \pm 0.01^{\mathrm{c}}$ & $0.30 \pm 0.01^{b}$ & $0.30 \pm 0.01^{b}$ \\
\hline & 15 & $0.42 \pm 0.02^{\mathrm{e}}$ & $0.48 \pm 0.02^{\mathrm{c}}$ & $0.48 \pm 0.02^{c}$ & $0.48 \pm 0.03^{\mathrm{c}}$ & $0.46 \pm 0.02^{b}$ \\
\hline & 30 & $0.50 \pm 0.03^{\mathrm{a}}$ & $0.56 \pm 0.03^{c}$ & $0.56 \pm 0.03^{c}$ & $0.56 \pm 0.02^{c}$ & $0.52 \pm 0.03^{b}$ \\
\hline & 45 & $0.60 \pm 0.04^{\mathrm{a}}$ & $0.64 \pm 0.02^{b}$ & $0.65 \pm 0.02^{c}$ & $0.65 \pm 0.04^{c}$ & $0.64 \pm 0.01^{b}$ \\
\hline \multirow{4}{*}{$\begin{array}{l}\text { T.V.F.A } \\
* *\end{array}$} & 0 & $3.30 \pm 0.02^{\mathrm{a}}$ & $3.90 \pm 0.04^{\mathrm{c}}$ & $3.90 \pm 0.04^{\mathrm{c}}$ & $3.90 \pm 0.02^{\mathrm{c}}$ & $3.50 \pm 0.02^{b}$ \\
\hline & 15 & $4.12 \pm 0.04^{\mathrm{a}}$ & $4.52 \pm 0.03^{\mathrm{c}}$ & $4.52 \pm 0.01^{\mathrm{c}}$ & $4.52 \pm 0.06^{\mathrm{c}}$ & $4.20 \pm 0.04^{b}$ \\
\hline & 30 & $5.90 \pm 0.01^{\mathrm{a}}$ & $6.20 \pm 0.01^{\mathrm{c}}$ & $6.20 \pm 0.03^{\mathrm{c}}$ & $6.20 \pm 0.02^{\mathrm{c}}$ & $5.96 \pm 0.03^{b}$ \\
\hline & 45 & $7.30 \pm 0.06^{\mathrm{a}}$ & $7.50 \pm 0.06^{b}$ & $7.50 \pm 0.06^{b}$ & $7.52 \pm 0.01^{\mathrm{c}}$ & $7.30 \pm 0.06^{\mathrm{a}}$ \\
\hline \multirow{4}{*}{$\begin{array}{l}\text { Ash } \\
(\%)\end{array}$} & 0 & $3.10 \pm 0.2^{\mathrm{a}}$ & $3.12 \pm 0.6^{\mathrm{b}}$ & $3.10 \pm 0.1^{\mathrm{a}}$ & $3.40 \pm 0.2^{\mathrm{d}}$ & $3.30 \pm 0.3^{\mathrm{c}}$ \\
\hline & 15 & $3.22 \pm 0.2^{\mathrm{a}}$ & $3.25 \pm 0.2^{\mathrm{b}}$ & $3.28 \pm 0.4^{\mathrm{c}}$ & $3.60 \pm 0.4^{\mathrm{e}}$ & $3.40 \pm 0.2^{\mathrm{d}}$ \\
\hline & 30 & $3.50 \pm 0.4^{\mathrm{a}}$ & $3.52 \pm 0.4^{b}$ & $3.55 \pm 0.5^{\mathrm{c}}$ & $3.68 \pm 0.2^{\mathrm{d}}$ & $3.52 \pm 0.4^{b}$ \\
\hline & 45 & $3.66 \pm 0.1^{\mathrm{a}}$ & $3.70 \pm 0.8^{\mathrm{b}}$ & $3.72 \pm 0.4^{c}$ & $3.72 \pm 0.6^{c}$ & $3.70 \pm 0.1^{b}$ \\
\hline
\end{tabular}

Averages with different superscripts differed significantly $(\mathrm{P} \leq 0.05)$.

${ }^{*} \mathrm{~T}_{1}$ : Tallaga cheeses treatments with added $0.5 \%$ Garlic oil, $\mathrm{T}_{2}$ : Tallaga cheeses treatments with added $0.5 \%$ Ginger oil, $\mathrm{T}_{3}$ : Tallaga cheeses treatments with added $0.5 \%$ Clove oil, $\mathrm{T}_{4}$ : Tallaga cheeses treatments with added $5 \%$ propolis extract $(10 \%)$,

**TVFA: total volatile fatty acids expressed as $\mathrm{ml} \mathrm{NaOH} 0.1 \mathrm{~N} / 100 \mathrm{~g}$ cheese, SP: Storage periods 
The percentage of fat in the Tallaga cheese from all treatments increased significantly $(\mathrm{P}<0.05)$ as storage period progressed mainly because of decrease in the moisture content (Kebary et al., 1996). During storage the fat content increased from $17.10 \%-17.35 \%$ when fresh to $19.40 \%-19.50 \%$ after 45 days of cold storage which can be attributed to the low in the moisture content of cheese. These results coincided with those reported for Domiati cheese by Al-Jasser and Al-Dogan, (2009).

Table (1) shows that the cheese acidity increased with increasing the storage period. The changes in $\mathrm{pH}$ value of cheese followed an opposite trend to change in total acidity. However, the development of acidity was slightly faster in cheeses with added oils and propolis extract whereas that containing 5\% propolis extract showed the highest acidity. The present results are in agreement with that of (Saleh, 2018). Statistical analysis showed that differences in TA due to treatments and storage period were significant $(\mathrm{P} \leq 0.05)$. As shown in Table (1), No significant difference $(\mathrm{P}<0.05)$ were observed in total nitrogen contents $(\mathrm{TN})$ of cheese from different treatments. The total nitrogen (TN \%) content decreased of all cheeses as storage period progressed, which may be the cause of the degradation of protein into soluble nitrogen (SN) and subsequent the loss of some water soluble nitrogen from the degraded protein at the brine. These results were in a great agreement with the reported by (El-Kholy, 2005). It could be observed from table (1) that the added oils and propolis extract affected the SN content of cheese. Tallaga cheese (control) showed the lowest soluble nitrogen content, while other treatments increased its soluble nitrogen content. SN contents increased as storage progressed. The same results were reported by (Al-Kholy 2005).cheeses made with as coagulant $0.5 \%$ ginger $0.5 \%$ clove oil $\left(\mathrm{T}_{2}\right.$ and $\left.\mathrm{T}_{3}\right)$ contained the highest soluble nitrogen content. The SN contents increased as storage progressed. The same of the results was reported by (El-Kholy 2005). It was noted that cheese made from milk treated with oil had higher rate of protein break down. The same of results were reported by (Al-Jasser and AL-Dong 2009). Tallaga cheese made from milk treated with oil had the highest $(\mathrm{p}<0.05)$ values of TVFA compared to other treatments. (Table 1) which can be exploited that the added oils were distilled in the cheese distillate to increase the TVFA values. The TVFA increased significantly $(p<0.05)$ in each chesses as storage period progressed. Slight differences were noticed among Tallaga cheese in ash content throughout storage period indicating that, addition of essential oils and propolis had little effect on the composition of the resulted cheese. 


\section{Microbiological Analysis}

Table (2) reveals average of total bacterial counts (TBC) of each treatment of Tallaga cheese samples. The results show that the TBC was higher in the control sample than treated samples. During storage period, these counts decreased gradually and reached its minimum level at the end period of cold storage. Count of yeast and molds is the most important parameters to determine the shelf life and quality of Tallaga cheese count of yeast and mould. In addition to quality deterioration, microbiological counts have been used as indices for the end of shelf life of dairy products (Miur and Banks, 2000) it is shown that yeast and molds could not be detected in fresh samples.

Table (2): Microbiological analysis of Tallaga cheeses treatments during storage period at $5^{\circ} \mathrm{c} \pm 1$.

\begin{tabular}{|c|c|c|c|c|c|c|}
\hline \multirow[t]{2}{*}{ Properties } & \multirow{2}{*}{$\begin{array}{c}\text { Storage } \\
\text { period } \\
\text { (days) }\end{array}$} & \multicolumn{5}{|c|}{ Treatment groups* } \\
\hline & & Control & $\mathbf{T}_{1}$ & $\mathbf{T}_{2}$ & $\mathbf{T}_{\mathbf{3}}$ & $\mathbf{T}_{4}$ \\
\hline \multirow{4}{*}{$\begin{array}{l}\text { Total } \\
\text { bacterial } \\
\text { counts } \\
\left(\text { count } \times 10^{6}\right. \\
\text { cfu**/g) }\end{array}$} & 0 & $42.00 \pm 4.0^{\mathrm{d}}$ & $33.00 \pm 4.0^{\mathrm{c}}$ & $32.00 \pm 3.0^{b}$ & $33.00 \pm 2.0^{\mathrm{c}}$ & $31.00 \pm 2.0^{\mathrm{a}}$ \\
\hline & 15 & $35.00 \pm 3.0^{\mathrm{d}}$ & $23.00 \pm 2.0^{b}$ & $23.00 \pm 2.0^{\mathrm{b}}$ & $24.00 \pm 3.0^{\mathrm{c}}$ & $20.00 \pm 1.0^{\mathrm{a}}$ \\
\hline & 30 & $22.00 \pm 2.0^{\mathrm{c}}$ & $13.00 \pm 2.0^{\mathrm{a}}$ & $14.00 \pm 1.0^{\mathrm{b}}$ & $14.00 \pm 1.0^{b}$ & $13.00 \pm 1.0^{\mathrm{a}}$ \\
\hline & 45 & $17.00 \pm 1.0^{\mathrm{d}}$ & $12.00 \pm 1.0^{\mathrm{c}}$ & $11.00 \pm 1.0^{b}$ & $11.00 \pm 1.0^{\mathrm{b}}$ & $10.00 \pm 1.0^{\mathrm{a}}$ \\
\hline \multirow{4}{*}{$\begin{array}{l}\text { Total mold } \\
\text { and yeast } \\
\text { counts } \\
\left(\text { count } \times 10^{2}\right. \\
\text { cfu**/g) }\end{array}$} & 0 & ND & ND & ND & ND & ND \\
\hline & 15 & $3.00 \pm 2.0^{\mathrm{b}}$ & $\mathrm{ND}^{\mathrm{a}}$ & $\mathrm{ND}^{\mathrm{a}}$ & $\mathrm{ND}^{\mathrm{a}}$ & $\mathrm{ND}^{\mathrm{a}}$ \\
\hline & 30 & $6.00 \pm 2.00^{\mathrm{c}}$ & $0.1 \pm 0.02^{\mathrm{a}}$ & $0.2 \pm 0.01^{b}$ & $0.1 \pm 0.03^{\mathrm{a}}$ & $0.1 \pm 0.02^{\mathrm{a}}$ \\
\hline & 45 & $10.00 \pm 2.0^{\mathrm{d}}$ & $0.40 \pm 0.15^{\mathrm{a}}$ & $0.60 \pm 0.30^{c}$ & $0.50 \pm 0.20^{b}$ & $0.40 \pm 0.30^{\mathrm{a}}$ \\
\hline \multirow{4}{*}{$\begin{array}{l}\text { Coliform } \\
\text { count } \\
\left(\text { count } \times 10^{2}\right. \\
\text { cfu**/g) }\end{array}$} & 0 & ND & ND & ND & ND & ND \\
\hline & 15 & ND & $\mathrm{ND}$ & ND & ND & $\mathrm{ND}$ \\
\hline & 30 & ND & ND & ND & ND & $\mathrm{ND}$ \\
\hline & 45 & $0.40 \pm 0.11^{\mathrm{c}}$ & $\mathrm{ND}^{\mathrm{a}}$ & $0.07 \pm 0.06^{b}$ & $\mathrm{ND}^{\mathrm{a}}$ & $0.09 \pm 0.04^{b}$ \\
\hline
\end{tabular}

Data are mean \pm SE for 3 replicates.

Averages with different superscripts differed significantly $(\mathrm{P} \leq 0.05)$.

*See legend to Table (1) for details.

$* * \mathrm{cfu}$ : colony forming unit.

Although, the counts began to be detected and counted over 30 days in each treatments including control. These results agreed with the results reported by (Mehanna et al., 2002) who showed that the yeast and molds of soft cheese started to appear after 15 days of storage period. The counts of mould and yeast were lower than allowed according to (EOS, 2000) being not more than $100 \mathrm{cfu} / \mathrm{g}$. During storage period the yeast and could 
increase gradually by the end of storage period for control. These results are in no agreement with (Diabiza, 2006) who found that the addition of ginger decreased the total bacterial counts and mould \& yeast. The resultant cheese was characterized by small proportions of coliform.

\section{Organoleptic properties:-}

Tallaga cheeses were evaluated for appearance and body \& texture and flavour. Data pertaining to the overall evaluation and preference of fresh Tallaga cheese are depicted in Table 3. Results of the sensory evaluation of Tallaga cheese manufactured by adding $0.5 \%$ oils and $5 \%$ propolis extract treatments $\mathrm{T}_{1}, \mathrm{~T}_{2}, \mathrm{~T}_{3}$ and $\mathrm{T}_{4}$ gained higher score for appearance, body and texture and flavour than control at zero time. Adding different ratio of oil were the principal factors influencing the sensory properties of prepared cheeses.

Table (3): Sensory evaluation of Tallaga cheeses treatments during storage period at $5^{\circ} \mathrm{c} \pm 1$.

\begin{tabular}{|c|c|c|c|c|c|c|}
\hline \multirow{2}{*}{ Properties } & \multirow{2}{*}{$\begin{array}{c}\text { Storage } \\
\text { period (days) }\end{array}$} & \multicolumn{5}{|c|}{ Treatment groups* } \\
\hline & & Control & $T_{1}$ & $\mathbf{T}_{2}$ & $\mathbf{T}_{3}$ & $\mathbf{T}_{4}$ \\
\hline \multirow{4}{*}{$\begin{array}{l}\text { Flavour } \\
\text { (50 points) }\end{array}$} & 0 & $45 \pm 0.11^{\mathrm{a}}$ & $46 \pm 0.12^{b}$ & $47 \pm 0.10^{c}$ & $46 \pm 0.12^{b}$ & $47 \pm 0.12^{c}$ \\
\hline & 15 & $45 \pm 0.10^{\mathrm{a}}$ & $47 \pm 0.14^{b}$ & $47 \pm 0.11^{b}$ & $47 \pm 0.12^{b}$ & $47 \pm 0.14^{b}$ \\
\hline & 30 & $44 \pm 0.22^{\mathrm{a}}$ & $47 \pm 0.11^{\mathrm{c}}$ & $47 \pm 0.20^{c}$ & $46 \pm 0.22^{b}$ & $46 \pm 0.16^{b}$ \\
\hline & 45 & $43 \pm 0.12^{a}$ & $47 \pm 0.20^{b}$ & $47 \pm 0.16^{b}$ & $47 \pm 0.10^{b}$ & $47 \pm 0.18^{b}$ \\
\hline \multirow{4}{*}{$\begin{array}{l}\text { Body \& } \\
\text { Texture } \\
\text { (40 points) }\end{array}$} & 0 & $37 \pm 0.20^{\mathrm{a}}$ & $39 \pm 0.18^{c}$ & $39 \pm 0.18^{\mathrm{c}}$ & $38 \pm 0.22^{b}$ & $39 \pm 0.22^{c}$ \\
\hline & 15 & $36 \pm 0.14^{\mathrm{a}}$ & $38 \pm 0.20^{b}$ & $38 \pm 0.20^{b}$ & $38 \pm 0.18^{b}$ & $38 \pm 0.20^{b}$ \\
\hline & 30 & $35 \pm 0.20^{\mathrm{a}}$ & $36 \pm 0.18^{b}$ & $37 \pm 0.16^{c}$ & $36 \pm 0.20^{b}$ & $37 \pm 0.22^{c}$ \\
\hline & 45 & $34 \pm 0.22^{\mathrm{a}}$ & $35 \pm 0.24^{b}$ & $35 \pm 0.22^{b}$ & $35 \pm 0.18^{b}$ & $36 \pm 0.18^{d}$ \\
\hline \multirow{4}{*}{$\begin{array}{l}\text { Appearance } \\
\text { (10 points) }\end{array}$} & 0 & $8 \pm 0.06^{\mathrm{a}}$ & $9 \pm 0.06^{b}$ & $9 \pm 0.06^{b}$ & $9 \pm 0.04^{b}$ & $9 \pm 0.06^{b}$ \\
\hline & 15 & $7 \pm 0.02^{a}$ & $8 \pm 0.03^{b}$ & $9 \pm 0.01^{c}$ & $8 \pm 0.02^{b}$ & $9 \pm 0.03^{c}$ \\
\hline & 30 & $7 \pm 0.01^{\mathrm{a}}$ & $8 \pm 0.02^{b}$ & $8 \pm 0.06^{b}$ & $8 \pm 0.06^{b}$ & $8 \pm 0.04^{b}$ \\
\hline & 45 & $7 \pm 0.04^{\mathrm{a}}$ & $7 \pm 0.04^{\mathrm{a}}$ & $8 \pm 0.02^{b}$ & $7 \pm 0.04^{\mathrm{a}}$ & $8 \pm 0.03^{b}$ \\
\hline \multirow{4}{*}{$\begin{array}{l}\text { Total } \\
\text { acceptance } \\
\text { (100 points) }\end{array}$} & 0 & $90 \pm 0.22^{\mathrm{a}}$ & $94 \pm 0.26^{c}$ & $95 \pm 0.30^{\mathrm{d}}$ & $93 \pm 0.022^{b}$ & $95 \pm 0.28^{\mathrm{d}}$ \\
\hline & 15 & $89 \pm 0.40^{\mathrm{a}}$ & $93 \pm 0.38^{b}$ & $94 \pm 0.30^{c}$ & $93 \pm 0.40^{b}$ & $94 \pm 0.40^{c}$ \\
\hline & 30 & $86 \pm 0.22^{\mathrm{a}}$ & $91 \pm 0.32^{c}$ & $92 \pm 0.26^{\mathrm{d}}$ & $90 \pm 0.20^{b}$ & $91 \pm 0.30^{c}$ \\
\hline & 45 & $84 \pm 0.60^{\mathrm{a}}$ & $89 \pm 0.58^{b}$ & $90 \pm 0.64^{c}$ & $89 \pm 0.60^{b}$ & $91 \pm 0.62^{d}$ \\
\hline
\end{tabular}

Data are mean \pm SE for 3 replicates.

Averages with different superscripts differed significantly $(\mathrm{P} \leq 0.05)$.

*See legend to Table (1) for details.

Meanwhile the cheese processed with propolis 5\% gained the highest score for all storage period. In general all cheese made with different types 
of essential oils had acceptable appearance and body \&texture during storage period. These results are in a line with those obtained by Abd ElSalam and Benkerram, 2007). It could be concluded that propolis (5\%), clove, ginger and garlic $0.5 \%$ essential oils can be used for improvement of the quality of Tallaga cheese and it can increase the shelf life of Tallga cheese for longer with imparting good flavour. Finally, from the fore mentioned results, it can be recommended that some naturally essential oils gave good sensory characteristics when used at the certain concentrations in Tallaga cheese. Also, it can be successfully applied to increase the shelf life of Tallaga cheese made with the specific concentrations of those oils of storage at the refrigeration temperature.

Conclusively, results of this study showed that can produce high quality Tallaga cheese and accept the use of some essential oils can be recommended. The finished product showed improved body texture, better cheese flavor. Moreover, prolong the life of the cheese. Much research is needed to continue applying these essential oils in compounds with others and with each other atural preservatives, and also investigate the effect of these oils on the spoilage in other types of dairy foods.

\section{REFERENCES}

Abd-Alla, M.S., Atalla, K.M., Ghazi I.M., and Galal, E.A. (2000). Effect of some aqueous plant extracts on microbiological, chemical and organoleptic properties of ultrafiltered cheese. Annals Agric. Sci. Ain Shams Univ. Cairo, 45: 409.

Abd El-Salam, M. H. and Benkerrom. N. (2007). North African brined cheese- in Brined cheese (Ed) A\%Tamime, Blackwell Pub. Pp.139- 187.

Abou-Dawood, S.A.I. (1996). Use of some spices as natural preservatives for some dairy products. M.Sc. Thesis, Fac. of Agric, Cairo Univ. Egypt.

Ahmed, T.K. and Abd El-Razig K.A. (1998). Manufacture of Gibna Beida (white soft cheese) from cows' and goats' milk. Egyptian J. Dairy Sci. 26: 167.

Al- Jasser, M. S. and Al- Dogan, A. A.(2009). Properties of white soft cheese produced using rennet substitute extracted from Solanum dubium seeds. Egyptian J. Dairy Sci. 37: 237.

APHA (2003). Compendium of Methods for the Microbiological Examination of Foods. 3 rd Ed.(Vanderzant, C and Splittoesser, D. eds) Washington DC, USA, p.675.

AOAC (2012). Official Methods of Analysis, $19^{\text {th }} \mathrm{Ed}$. Vol (2), Arlington VA. USA. 
Aureli, P.; Consrantini, A. and Zolea, A. (1992). Antimicrobial activity of some essential oils against Listeria monocyte - genes. J. Food Prot. 55:344

Bowles, B. L. and Juneja, K. V. (1998). Inhibition of food-borne bacterial pathogens by naturally occurring food additives. J. Food Safety 18: 101.

Bullerman, L. B. ; Lieu, F. Y. and Seier, S. A. (1977). Inhibition of growth and aflatoxin production by cinnamon and clove oils, cinnamic aldehyde and eugenol. J. Food Sci., 42: 1107.

Clark, W. S., Brazis, Jr. A. R., Fowler, J. L., Johns, C. K., Nelson, F. E., (1978). Standard plate count method. Ch. 5 In: Standard Methods for the Examination of Dairy Products. Edited by E. H. Marth, 14th, American Public Health Association, DC, U.S.A.

Dabiza, M.A.( 2006). Improvement of ripening and safety of ras cheese using propolis and eugenol. Egyptian J. dairy sci., 34:185.

Duncan, D.B. (1955): Multiple Rang and Multiple F-Test Biometrics, 11: 1-42

EOS (2000). Egyptian standard for Kareish and Domiati cheese. Egyptian Organization for standards, quality and control .ES 1008/2000.

El- Kholy, A. M., (2005). Influence of Transglutaminase (TGASE) enzyme on the quality of low fat Tallaga cheese. J Agric. Sci. Mansoura Univ. 30: 5419.

Fahmi, A. H. and Sharara, H. A. (1950). Study on Egyptian Domiati cheese. J. Dairy Res.; 17: 312.

El-Nimer, T.M.; Awad, M. S. and Ali, H. A. (2003). Increasing of probiotic and therapeutic action in Karish cheese using toluene balsam extract. Egyptian. J. Food Sci., 31: 213.

Gould, G. W. (1996). Industry perspective on the use of natural antimicrobials and inhibitors for food applications. J. Food Prot. (Suppl.):82.

Hassan, H. N. and El-Deeb, S. A. (1988). The inhibitory effect of water and acetone extractions of certain plants as antifungal agents on growth and aflatoxins production by mold and yeast isolated from cheese ripening rooms. J. Agric. Res. Tanta Univ., 14:162

Hofi , A.A., Nour, M., El-Nagar, S. and El-Shibiny, S. (1979). Chemical composition and quality of market cold stored soft cheese. Egyptian J. Dairy Sci., 7: 87-91.

Hosny I. M., El Kholy W. I., Murad H.A., El Dairouty R.K., (2011). Antimicrobial activity of Curcumin upon pathogenic microorganisms during manufacture and storage of a novel style cheese 'Karishcum". Journal of American Science, 7: 611. 
Hussein G.A.M.,(2004). Manufactured of flavourd Tallaga cheese. Egyptian J. Dairy Sci., 32: 277.

Ismail, A.M., S. Harby, Aida. S. Salem (2006). Production of flavored labneh with extended shelf life. Egyptian J. diary sci., 34:59.

Kebary, K. M. K.; Hamed, A. I.; Zedan, A. N. and El- Beheary, A. A. F. (2006). Manufacture of low fat Domiati cheese using Novagel. Egyptian J. Dairy Sci., 34: 175.

Kebary, K. M. K.; Kamaly, K. M.; Zedan, A. N. and Zaghlol, A. H. (1996). Acceleration ripening of Domiati cheese by accelase and lipozyme enzymes. Egyptian J.Dairy Sci., 24: 75-.

Kosikowski F.V.,(1978). Cheese and Fermented Milk Foods. $2^{\text {nd }}$ ed. Cornell Univ. Ithaca, New York.

Lawson, L. D. (1993). Bioactive organosulfur compounds: role in reducing blood lipids, in Human Medicinal Agents, 306 330, D. King horn and M. F. Balaandrin Eds., ACS symposium Series 534.

Mehanna, N.M. and Rashed, M.A. (1990). An attempt to improve the keeping quality of tallaga cheese by using milk treated with carbon dioxide. Egyptian J. Dairy Sci., 18: 377-388.

Mehanna, S. N., Sharf, O. M., Ibrahim, G. A., and Tawfik, K. N., (2002). Incorporation and viability of some probiotic bacteria in functional dairy food. 1. Soft cheese, Egyptian. J. Dairy Sci., 30: 219.

Miur, D.D. and Banks, M. J. ( 2000). Milk and milk products. Pp.197219. in: The Stability and Shelf Life of Food. D. kileast and P .subramaniand. CRC press, Boca Roton FL.

Pappas, C. P.; Kondly, E.; Voustsinas, L. P. and Mallatou, H. (1996). Effect of starter level, draining time and aging on the physicochemical, organoleptic and rheological properties of Feta cheese. J. Soci. Dairy Technol. 49:73.

Saleh, A. E., (2018). Keeping quality of kareish chees as affected with added certein spices and herbs oil as antifungal agents. J. Food Dairy Sci., Mansoura. 9: 7.

SAS (2004). Users Group International Conference, Cary NC, SAS@ 9.1 SQL Procedure, SAS Institute Inc. Available in electronic form at.

Salvador, A., and Fiszman, M. S., (2004). Textural and sensory characteristics of whole and skimmed flavored set-type yogurt during long storage. J. Dairy Sci, 87:4033.

Shelef, L. A., Naglik, O.A., and Bogen, D. W., (1980). Sensitivity of common food- borne bacteria to the spices sage, rosemary, and allspice. J. Food Sci. 45: 1042. 
Sonia, A. H. M. (2011). Extended shelf life of kareish cheese by natural preservatives. Egypt. J. Agric. Res., 89: 639.

Tassou, C.C; Drosinos, H. E. and Nychas, J. G. E. (1995). Effect of essential oils from mint (Mentha piperita) on Salmonella enteritidis and Listeria monocytogenes in model food systemat $4: \mathrm{C}$ and $10: \mathrm{C}$. J. Appl. Bacteriol. 78:593

Verissimo, P.; Faro, C.; Moir, A. j. ; Lin, y.; Tang, J. and Pires, E.(1996). Purification, characterization and partial amino acid sequencing of two new aspartic proteinases from fresh flowers of Cynara cardunculus L. Eur J. Biochem. 235: 762.

\section{اطالة مدة حفظ الجبن الثلأجة المصنع باستخدام مواد حافظة طبيعية}

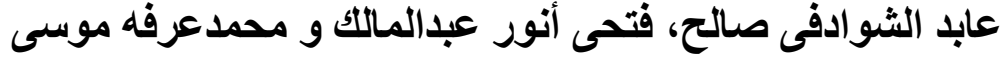

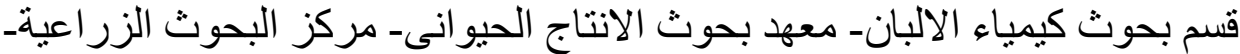

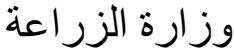

الجبن الثثلاجة من المنتجات الغذائية سريعة الفساد و ذلك لانها تحتوى عل هل

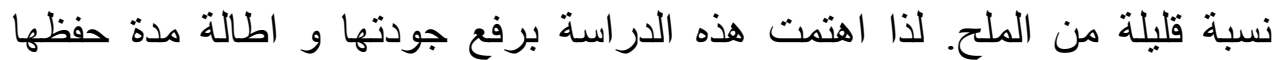
باستخدام بعض المواد الحافظة الطبيعية الأمنة على صحة المستهرلك. حيث تم در اسة الته

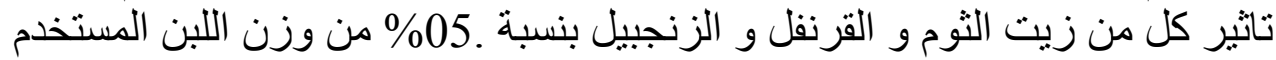

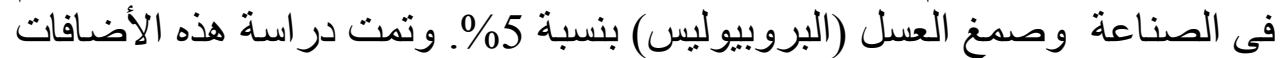

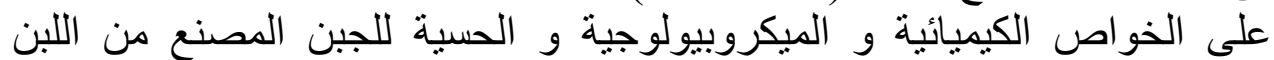

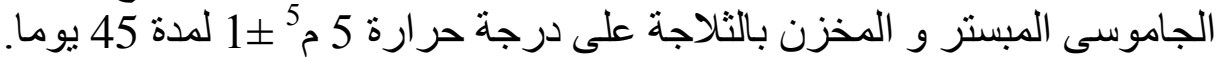

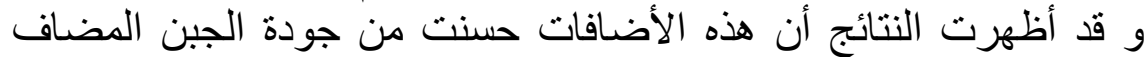

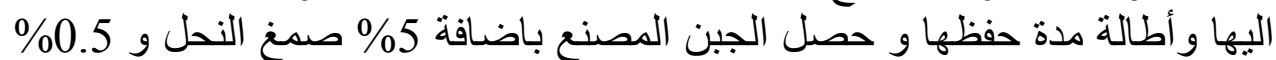
زيت الزنجبيل على أعلى النتائج الحسية مقارنة بالكنترول في نهاية فترة التخد التخزين.

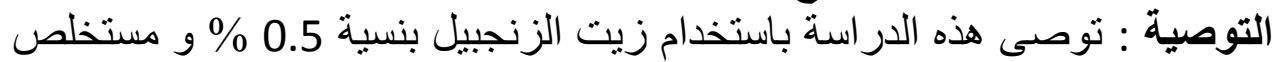
صمغ النحل (البروبيوليس) بنسية 5\% لتحسين خو اص الجبن وزيادة مده حفظها. 